УДК 618.16-006.6-036.2:618.173

DOI 10.11603/24116-4944.2020.2.11856

๑Т. Ф. Татарчук ${ }^{1}$ В. В. Дунаєвська ${ }^{1,2}$, Н. Ф. Захаренко ${ }^{3}$

${ }^{1}$ ДУ «Інститут педіатрї, акушерства і гінеколозї імені академіка О. М. Лук'янової \author{
НАМН України» \\ ${ }^{2}$ Національний інститут раку, м. Київ \\ ${ }^{3}$ ДНУ «Центр інноваційних медичних технологій НАН Украйни»

\section{ОСОБЛИВОСТІ КЛІНІЧНОГО ПЕРЕБІГУ ПЕРЕДРАКУ І РАКУ ВУЛЬВИ У ЖІНОК ПРЕ- І ПОСТМЕНОПАУЗАЛЬНОГО ВІКУ}

\begin{abstract}
Мета дослідження - вивчити особливості клінічного перебігу передраку і раку вульви у жінок пре- і постменопаузального віку.

Матеріали та методи. Із 2017 до 2020 рр. у поліклінічному відділенні Національного інституту раку обстежено 160 хворих із дистрофрічними захворюваннями, передраком і початковим раком вульви. Аналіз амбулаторних карт та історій хвороб усіх жінок дозволив нам додатково вивчити особливості клінічного перебігу патологічних процесів зовнішніх статевих органів залежно від віку. Вік хворих у дослідженні коливався від 49 до 70 років, у середньому $(59,6 \pm 3,5)$ року. Менструальна

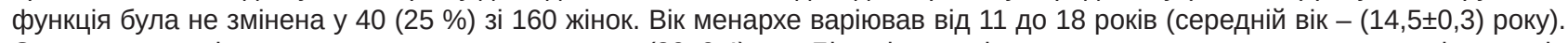
Середня тривалість менструального циклу склала $(30 \pm 0,4)$ дня. Більшість пацієнток неодноразово зверталася до гінекологів і дерматологів із приводу свербежу та дискомфорту в ділянці зовнішніх статевих органів. Лікар проводив консервативне лікування «лейкоплакії і краурозу» впродовж багатьох місяців, а іноді й років, без гістологічного уточнення діагнозу.

Результати дослідження та їх обговорення. При дослідженні біоптатів вульви переважали хворі із діагнозом раку вульви I A стадії (34 \%) порівняно з VIN (інтраепітеліальною неоплазією вульви) (12 \%). При цьому VIN і початковий рак вульви були асоційовані з вірусом папіломи людини лише в 37,5 \% випадків.

Висновок. Однією з особливостей клінічного перебігу неоплазій вульви у жінок пре- і постменопаузального віку є те, що злоякісний процес частіше виявляється на стадії моносокальної інвазивної пухлини.
\end{abstract}

Ключові слова: вульва; рак; передрак; анамнез; вульвоскопія; гістологічне дослідження.

ОСОБЕННОСТИ КЛИНИЧЕСКОГО ТЕЧЕНИЯ ПРЕДРАКА И РАКА ВУЛЬВЫ У ЖЕНЩИН ПРЕ- И ПОСТМЕНОПАУЗАЛЬНОГО ВОЗРАСТА

Цель исследования - изучить особенности клинического течения предрака и рака вульвы у женщин пре- и постменопаузального возраста.

Материалы и методы. С 2017 по 2020 гг. в поликлиническом отделении Национального института рака обследованы 160 больных с дистрофическими заболеваниями, предраком и начальным раком вульвы. Анализ амбулаторных карт и историй болезни всех женщин позволил нам дополнительно изучить особенности клинического течения патологических процессов наружных половых органов в зависимости от возраста. Возраст больных в исследовании колебался от 49 до 70 лет, в среднем $(59,6 \pm 3,5)$ года. Менструальная фрункция была не изменена у 40 (25 \%) из 160 женщин. Возраст менархе варьировал от 11 до 18 лет (средний возраст - $(14,5 \pm 0,3)$ года). Средняя продолжительность менструального цикла составила $(30 \pm 0,4)$ дня. Большинство пациенток неоднократно обращалось к гинекологам и дерматологам по поводу зуда и дискомфорта в области наружных половых органов. Врач проводил консервативное лечение «лейкоплакии и крауроза» на протяжении многих месяцев, а иногда и лет, без гистологического уточнения диагноза.

Результаты исследования и их обсуждение. При исследовании биоптатов вульвы преобладали больные с диагнозом рака вульвы I А стадии (34 \%) по сравнению с VIN (интраэпителиальной неоплазией вульвы) (12 \%). При этом VIN и начальный рак вульвы были ассоциированы с вирусом папилломы человека лишь в 37,5 \% случаев.

Вывод. Одной из особенностей клинического течения неоплазий вульвы у женщин пре- и постменопаузального возраста есть то, что злокачественный процесс чаще выявляется на стадии монофокальной инвазивной опухоли.

Ключевые слова: вульва; рак; предрак; анамнез; вульвоскопия; гистологическое исследование.

FEATURES OF THE CLINICAL COURSE OF VULVAR PRECANCER AND CANCER IN WOMEN OF PRE- AND POSTMENSTRUAL AGE

The aim of the study - to learn the features of the clinical course of precancerous lesions and vulvar cancer in pre- and postmenopausal women.

Materials and Methods. From 2017 to 2020, 160 patients with dystrophic diseases, precancerous lesions and early vulvar cancer were examined in the Outpatient Department of the National Cancer Institute. The analysis of outpatient cards and medical histories of all women allowed us to further study the features of the clinical course of pathological processes of the external genitalia depending on age. The age of patients in the study ranged from 49 to 70 years old (59.6 \pm 3.5$)$. Menstrual function was unchanged in $40(25 \%)$ of 160 women. The age of menarche varied from 11 to 18 years (mean age - (14.5 \pm 0.3 years). The average duration of the menstrual cycle was $(30 \pm 0.4)$ days. Most patients have repeatedly consulted gynecologists and dermatologists about itching and discomfort in the external genitalia. The doctor performed conservative treatment of "leukoplakia and kraurosis" for many months, and sometimes years, without histological clarification of the diagnosis.

Results and Discussion. In the study of vulvar biopsies, patients diagnosed with vulvar cancer stage IA (34 \%) dominated comparing with VIN (intraepithelial neoplasia of the vulva) (12\%). 
Conclusion. One of the features of the clinical course of vular neoplasia in women of pre- and postmenopausal age is that the malignant process is more often detected at the stage of monofocal invasive tumor.

Key words: vulva; cancer; precancer; anamnesis; vulvoscopy; histological examination.

ВСТУП. Ця патологія є візуально доступною фрормою злоякісної пухлини, проте більше 50 \% пацієнток госпіталізують до спеціалізованої лікувальної установи 3 поширеними формами захворювання, а ії частота серед злоякісних пухлин геніталій за останні роки збільшилася 35 до 8 \% [1-5]. Стабільне 4-е рангове місце раку вульви у структурі онкогінекологічної захворюваності створює неправдиве враження про стійкість і відносно сприятливу ситуацію, пов'язану з цією патологією. Неухильне зростання захворюваності на передрак, епітеліальний та інвазивний рак вульви істотно збільшує питому вагу цієї групи хворих. Втім, зараз $є$ усі підстави поліпшити систему ранньої діагностики і лікування цієї патології [2, 5-8]. Ні при якій іншій локалізації гінекологічного раку не простежується така тісна асоціація з постменопаузою та інволютивно-атрофічними процесами цього періоду життя жінки [6, 9-13].

Проте впродовж останніх 10 років 3'являються дані про зростання захворюваності у молодих, частка яких складає $15 \%$. Середній вік розвитку пухлинного процесу знизився із 55 до 35 років, що з особливою гостротою ставить питання розробки органозберігаючих методів лікування, застосування яких можливе тільки на ранніх стадіях пухлинного процесу (VIN, T in situ, T1) [11, 14-18]. Незважаючи на те, що дистрофічні захворювання вульви добре відомі клініцистам ще 3 кінця минулого століття, до останнього часу немає чіткого і повного уявлення [19] про їх етіологію і патогенез. Найкраще вивчено і обґрунтовано гормональну, вірусно-інфекційну (роль HPV) і нейроендокринну теорії.

Здавалося б, візуальна локалізація раку вульви повинна служити приводом для своєчасного встановлення діагнозу. Проте кожна друга пацієнтка надходить до спеціалізованої лікувальної установи із III-IV стадіями захворювання. У свою чергу, причиною кожного другого випадку поширеного раку є несвоєчасна діагностика [20]. Тривале лікування фонових процесів без морфологічної верифрікації діагнозу є головною причиною запізнілої діагностики [1, 2, 6, 15, 21-24].

Попередній діагноз патології вульви ґрунтується передусім на специфрічних скаргах, даних ретельного огляду і додаткових методах дослідження (вульвоскопія, цитологічне дослідження). При огляді оцінюють шкірно-слизові покриви великих і малих статевих губ, міру оволосіння, забарвлення, вологість, наявність патологічних елементів на шкірі. Вульвоскопія при дистрофічних захворюваннях і раку вульви у ряді випадків дозволяє виявити підозрілі ділянки, атипію судин, у більшості ж випадків виявляється гіперкератоз, який обмежує діагностичні можливості методу. Найчастіше цей метод діагностики дозволяє лише уточнити діагноз і вибрати ділянки для біопсії [5, 11, 14 $21,22,25,26]$. У клінічно ясних випадках раку, а також при виразкових фрормах початкової карциноми і меланоми цитологічне дослідження підтверджує діагноз. Водночас VIN і преінвазивний рак, при яких патологічні процеси починаються в глибоких шарах епідермісу, можуть не виявлятися при цитологічному дослідженні. На жаль, при цитологічному дослідженні рак вульви підтверджується тільки в 30 \% випадків, в інших виявляється дис- і паракератоз. 3 цієї ж причини недоцільно брати мазкивідбитки (Pap-smear) для цитологічного дослідження із тканин зовнішніх статевих органів. У роботах зарубіжних дослідників щодо діагностики захворювань вульви дано оцінку цитологічного методу. Проте через невтішні результати (чутливість методу - 32 \%) автори підкреслюють, що «золотим стандартом» нині залишається гістологічне дослідження патології вульви, інфрормативність якого значною мірою визначається точним вибором місця біопсії $[5,7,11,12,14,25,27]$.

МЕТА ДОСЛІДЖЕННЯ - виявлення особливостей клінічного перебігу передраку і раннього раку вульви у жінок пре- і постменопаузального віку.

МАТЕРІАЛИ ТА МЕТОДИ. Із 2017 до 2020 рр. у поліклінічному відділенні Національного інституту раку 160 хворим із дистрофрічними захворюваннями, передраком і початковим раком вульви проведено повний комплекс обстежень 3 аналізом клінічних особливостей і виявленням послідовності дії різних чинників, що формують передумови для розвитку дистрофрічних захворювань і неоплазій вульви.

Аналіз амбулаторних карт та історій хвороби усіх жінок дозволив нам додатково вивчити особливості клінічного перебігу патологічних процесів зовнішніх статевих органів залежно від віку. Вік хворих у дослідженні коливався від 49 до 70 років, у середньому $(59,6 \pm 3,5)$ року.

Менструальна фрункція була не змінена у 40 (25\%) зі 160 жінок. Вік менархе варіював від 11 до 18 років (середній вік - $(14,5 \pm 0,3)$ року). Середня тривалість менструального циклу склала $(30 \pm 0,4)$ дня. Таким чином, значних порушень менструальної фрункції не виявлено. Більшість пацієнток неодноразово зверталася до гінекологів і дерматологів із приводу свербежу та дискомфорту в ділянці зовнішніх статевих органів. Лікар проводив консервативне лікування «лейкоплакії і краурозу» впродовж багатьох місяців, а іноді й років, без гістологічного уточнення діагнозу. Більш ніж у половини ( $\mathrm{n}=113 ; 71 \%)$ хворих проводили тривалу і необґрунтовану протизапальну або гормональну терапію з незадовільними результатами без цитологічного/гістологічного дослідження, спрямовану лише на ліквідацію симптомів.

Тривалість анамнезу в 54,5 \% випадків перевищила 1 рік. Впродовж цього періоду призначення різних мазей і кремів, седативних засобів, вітамінів, гормональних препаратів нерідко знімало або зменшувало свербіж, дискомсорт і больові відчуття. Хворі, відчувши полегшення, переставали відвідувати лікаря. Згодом у $40 \%$ пацієнток були виявлені диспластичні процеси різної міри вираження і початкові форми раку вульви. Усе вищесказане служить приводом для критичного перегляду методик обстеження пацієнток із цією патологією. Неадекватне трактування скарг і об'єктивних даних, отриманих у процесі огляду жінок, недостатня онкологічна 
настороженість лікарів і відсутність належного клінічного досвіду для правильної оцінки стану зовнішніх статевих органів призводять до зростання числа запущених фрорм пухлинних процесів.

Згідно з даними планового гістологічного дослідження біоптатів вульви, діагноз «склеротичний лишай» було встановлено у 46 (29\%) хворих, «плоскоклітинна гіперплазія» - у 40 (25\%) хворих, «інтраепітеліальна неоплазія вульви» (VIN I-VIN III) - у 20 (12 \%) хворих, «рак вульви І А стадії» - у 54 (34 \%) хворих (табл. 1).

Таблиця 1. Розподіл пацієнток за морфологічною структурою патології процесів вульви

\begin{tabular}{|l|c|c|}
\hline \multirow{2}{*}{ Дані морфологічного дослідження } & \multicolumn{2}{|c|}{ Кількість хворих } \\
\cline { 2 - 3 } & (абс.) & $\%$ \\
\hline Склеротичний лишай & 46 & 29 \\
\hline Плоскоклітинна гіперплазія & 40 & 25 \\
\hline VIN I & 2 & 1 \\
\hline VIN II & 8 & 5 \\
\hline VIN III & 10 & 6 \\
\hline Рак вульви I А стадії & 54 & 34 \\
\hline Разом & 160 & 100 \\
\hline
\end{tabular}

Таким чином, переважали хворі 3 діагнозом «рак вульви I А стадії» (34 \%) порівняно з VIN (12 \%). Клінічно ранній рак вульви був представлений у вигляді невеликого вузлика або бородавчастого, схожого на кольорову капусту, утворення. У 6 пацієнток ураження вульви були представлені гіперпігментованими утвореннями світлокоричневого кольору, що височіють над поверхнею.

У 29 \% жінок у пре- і постменопаузі виявлено склеротичний лишай, що пов'язує це захворювання з віковими змінами вульви. Клінічна картина склеротичного лишаю відзначалася давністю і вираженням патологічного процесу. Якщо в ранній період захворювання у більшості хворих шкірно-слизовий покрив був депігментований, білястого кольору, то у міру прогресу захворювання відзначали зниження оволосіння в ділянці лобка і великих статевих губ, шкірно-слизові покриви були згладжені, відзначали їх складчастість із порушенням еластичності.

Провідним симптомом (93 \%) у хворих цієї групи був невтихаючий і тяжкий свербіж, який у більшості випадків призводив до втрати працездатності і зниження якості життя. Найімовірніше, в основі свербежу лежать порушення у трофріці тканин зовнішніх статевих органів, які призводять до стоншування, сухості, появи тріщин і саден внаслідок розчухувань. Відзначено хворобливість, печіння, відчуття сухості, напруження і стягання шкірнослизових покривів. У пацієнток із тривалим анамнезом захворювання (54,5 \%), коли склероз і атрофія ставали більш вираженими, клітор і малі статеві губи майже не визначалися. Великі губи у вигляді потовщених валиків обмежували різко звужений вхід у піхву, шкірно-слизові покриви ставали ригідними і набули перламутрового відтінку.

Наступний етап дослідження був пов'язаний з вивченням інфекційної складової при передраку і початковому раку зовнішніх статевих органів. Слід звернути увагу на повну відсутність обстежень, спрямованих на виявлення папіломавірусної інфекції (ПВІ) у жінок пре- і постмено- паузального віку. Зазвичай лікарі гінекологи при огляді встановлювали діагноз «крауроз вульви» (термінологія старої класифрікації). Обстеження обмежували візуальним оглядом і призначенням мазей для зняття свербежу. Проте сьогодні багато авторів пов язують зростання частоти раку вульви зі збільшенням кількості жінок з ПВІ, що свідчить про важливу роль вірусу папіломи людини (ВПЛ) у багатоступінчастому процесі канцерогенезу [8, 10, 15, 17, 25, 29-30]. У проведеному дослідженні тестування на ДНК ВПЛ вульви методом полімеразної ланцюгової реакції (ПЛР) було виконано усім хворим. Серед жінок пре- і постменопаузального віку ПВІ виявлено у 60 (37,5 \%) хворих. При цьому 16-й і 18-й типи було виявлено у 29 (48 \%) хворих; 31-й і 33-й типи - у 14 (23\%) пацієнток; 6-й і 11-й типи - у 29 (48 \%) хворих, ВПл був відсутній у 100 (63 \%) пацієнток (табл. 2).

Таблиця 2. Типи вірусу папіломи людини у пацієнток пре- і постменопаузального віку

\begin{tabular}{|l|c|c|}
\hline \multirow{2}{*}{ Тип вірусу } & \multicolumn{2}{|c|}{ Кількість хворих } \\
\cline { 2 - 3 } & (абс.) & $\%$ \\
\hline 16-й і 18-й типи & 29 & 48 \\
\hline 31-й і 33-й типи & 14 & 23 \\
\hline 6-й і 11-й типи & 29 & 48 \\
\hline Відсутність ВПЛ & 100 & 63 \\
\hline
\end{tabular}

Необхідно відмітити, що ПВІ у переважного числа хворих не супроводжувалася ніякими клінічними проявами.

РЕЗУЛЬТАТИ ДОСЛІДЖЕННЯ ТА ЇХ ОБГОВОРЕННЯ. Таким чином, інфрікованість ПВІ у пацієнток у пре- і постменопаузі в цьому дослідженні невисока (37,5\%), але представлена різноманітним спектром ВПЛ як високого онкогенного ризику: 16, 18, 31 і 33-й типи (48 і 23 \% відповідно), так і низького онкогенного ризику - 6-й і 11-й типи (48 \%) майже в рівних співвідношеннях. При цьому VIN i початковий рак вульви у жінок цієї групи були асоційовані з ВПЛ лише в 37,5 \% випадків.

У жінок в пре- і постменопаузі у зв' язку з переважанням фронових дистрофрічних змін у вигляді склеротичного лишаю морфологічний діагноз VIN різної міри встановлюють досить рідко, частіше діагностують інвазивний рак. Аналіз вищесказаного дозволяє вважати склеротичний лишай захворюванням, що передує раку зовнішніх статевих органів. Цей контингент хворих необхідно ретельно і комплексно обстежувати з постійним динамічним спостереженням [22, 26, 27, 31, 32].

Таким чином, висока частота несвоєчасної діагностики початкового раку вульви зумовлена тривалим самолікуванням пацієнток, необґрунтованою протизапальною і гормональною терапією, неправильним взяттям матеріалу для цитологічного і гістологічного досліджень і відсутністю онкологічної настороженості у лікарів гінекологів загальної практики [1, 2, 6, 15, 25, 27, 32].

ВисновкИ. 1. Діагноз передраку або початкового раку, що розвивається на фоні дистрофічних уражень вульви, встановити важко. Існуючі методи діагностики недостатньо ефективні, тому повинні враховуватися чинники ризику (вірусна інфекція, біологічна агресивність пухлини), що дозволяють відібрати контингент хворих 
із патологією зовнішніх статевих органів. У цій ситуації грамотне планування діагностики і її висококваліфрікована реалізація відіграють вирішальну роль для долі хворої. Однією $з$ особливостей клінічного перебігу неоплазій вульви у жінок пре- і постменопаузального віку $є$ те, що злоякісний процес частіше виявляється на стадії монофрокальної інвазивної пухлини.

2. Зусилля вчених різних країн впродовж багатьох десятиліть спрямовані на розробку нових ефективних підходів у діагностиці злоякісних новоутворень вульви. До сьогодні накопичено значний науковий і клінічний матеріал, але результати діагностики хворих із злоякісними пухлинами вульви не можуть розцінюватися як задовільні і вимагають проведення подальших досліджень.

ПЕРСПЕКТИВИ ПОДАЛЬШИХ ДОСЛІДЖЕНЬ. ПОтребують подальшого дослідження механізми виникнення передраку та початкового раку, які розвиваються на фоні дистрофрічних уражень вульви.

\section{СПИСОК ЛІТЕРАТУРИ}

1. Бохман Я. В. Руководство по онкогинекологии / Я. В. Бохман. - СПб. : Фоліант, 2002. - 542 с.

2. Жаров А. В. Оптимизация лечения больных раком вульвы / А. В. Жаров, А. В. Важенин. - Челябинск, 2005. - 131 с.

3. Состояние онкологической помощи населению России в 2015 году / под ред. А. Д. Каприна, В. В. Старинского, Г.В.Петровой. - М. : МНИОИ им. П. А. Герцена - филиал ФГБУ «НМИРЦ» Минздрава России, 2016. - 236 с.

4. Злокачественные новообразования в России: обзор статистической информации за 1993-2013 годы / Г. В. Петрова, А. Д. Каприн, О. П. Грецова, В. В. Старинский. - М., 2015. -511 с.

5. Манухин И. Б. Заболевания наружных половых органов у женщин / И. Б. Манухин, Н. И. Кондриков, Т. П. Крапошина. - Изд-во : МИА, Россия, 2002. - 303 с.

6. Рак вульвы: этиопатогенетическая концепция / [Л. А. Ашрафян, Н. В. Харченко, В. И. Киселев и др.]. - М. : Молодая гвардия, 2006. - 192 с.

7. Кауфман Р. Д. Доброкачественные заболевания вульвы и влагалища / Р. Д. Каусрман, Д. Браун, С. Фаро ; пер. с англ. Н. И. Могилевская. - М. : Бином, 2009. - 544 с.

8. Imiquimod in cervical, vaginal and vulvar intraepithelial neoplasia: a review / C. J. de Witte, A. J. van de Sande, H. J. van Beekhuizen [et al.] // Gynecol. Oncol. - 2015. Vol. 139 (2). - P. 377-384.

9. Ашрафян Л. А. Опухоли репродуктивных органов (этиология и патогенез) / Л. А. Ашрасян, В. И. Киселев. - М. : Димитрейд График Групп, 2007. - 216 с.

10. Фотодинамическая терапия дистросрических заболеваний вульвы в сочетании с папилломавирусной инсрекцией / А. 3. Хашукоева, О. Б. Отдельнова, Е. С. Купеева // Лечение и профилактика. - 2012. - № 1 (2). - С. 78-80.

11. Уилкинсон Е. Дж. Болезнь вульвы : клинич. руков. / Е. Дж. Уилкинсон, К. И. Стоун. - М. : Бином, 2009. - 248 с.

12. Del Pino M. Pathways of vulvar intraepithelial neoplasia and squamous cell carcinoma // M. Del Pino, L. RodriguezCarunchio, J. Ordi // J. Histopathology. - 2013. - Vol. 62 (1) - P. 161-175.

13. Foster D. C. Vulvar disease / D. C. Foster // Obstet. Gynecol. - 2002. - Vol. 100 (1). - P. 145-163.

14. Дисаи Ф. Дж. Клиническая онкогинекология : в 3-х т. Т. 1. / Ф. Дж. Дисаи, У. Т. Крисман ; под ред. Е. Г. Новиковой. - Изд-во : Рид Элсивер, 2011. - 316 с.

15. Урманчеева А. Ф. Практическая онкоэкология : избранные лекции / А. Ф. Урманчеева, С. А. Тюляндин, В. М. Моисеенко. - СПб. : Центр Томми, 2008. - 400 с.

16. Stehman F. B. Carcinoma of the vulva / F. B. Stehman, K. Y. Look // Obstet. Gynecol. - 2006. - Vol. 107 (3). - P. 719-733.

17. Chovanec J. Preinvasive lesions in gynecology - vulva / J. Chovanec, L. Moukova, R. Feranec // Klin. Onkol. - 2013. Vol. 26 suppl. - P. S44-S46.

18. ACOG Committee Opinion No. 509: Management of vulvar intraepithelial neoplasia // Obstet. Gynecol. - 2011. Vol. 118 (5). - P. 1192-1194.
19. Morphological features of uterine polyps in females of reproductive age / N. Y. Gorban, T. D. Zadorozhna, I. B. Vovk, I. V. Zhulkevych // Вісник наукових досліджень. - 2019. № 2. - C. 47-52.

20. Жулкевич І. В. Персоналізація в онкології: індивідуальний підхід до профрілактики тромбоемболічних ускладнень при пангістеректомії / І.В.Жулкевич, Б. Д. Кривокульський // Вісник соціальної гігієни та організації охорони здоров'я України. - 2018. - № 4 (78). - С. 11-18.

21. Черенков В. Г. Рак вульвы: патогенетические варианты, диагностика, лечение, пластические операции / В. Г. Черенков, И.В.Александрова, А.А.Шпенкова // Опухоли женской репродуктивной системы. - 2010. - № 4. - С. 78-82. https://doi.org/10.17650/1994-4098-2010-0-4-78-82.

22. Wallbillich J. J. Vulvar intraepithelial neoplasia (VIN 2/3): comparing clinical outcomes and evaluating risk factors for recurrence / J. J. Wallbillich, H. E. Rhodes, A. M. Milbourne // Gynecol. Oncol. - 2012. - Vol. 127 (2). - P. 312-315.

23. Horban N. Y. Peculiarities of uterine cavity biocenosis in patients with different types of endometrial hyperproliferative pathology / N. Y. Horban, I. B. Vovk, T. O. Lysiana // J. Med. Life. - 2019. - Vol. 12 (3). - P. 266-270.

24. Бореліозна лімсраденопатія у практиці онколога (клінічні спостереження) / І. Й. Галайчук, І.В.Жулкевич, С. І. Сміян [та ін.] // Онкология. -2019. - Т. 21, № 3. - С. 250-253. DOI: 10.32471/oncology.2663-7928.t-21-3-2019-7896. URL: https://www.oncology.kiev.ua/article/7896/borelioznalimfadenopatiya-u-praktici-onkologa-klinichni-sposterezhennya.

25. Чулкова О. В. Диагностика и лечение фоновых и предраковых заболеваний вульвы / О. В. Чулкова, Е. Г. Новикова, В. В. Соколов // Практическая онкология. - 2006. T. 7, № 4. - C. 197-204.

26. Two distinct pathways to development of squamous cell carcinoma of the vulva / U. Yutaka, E. Takayuki, K. Toshihiro [et al.] // J. Skin Cancer. - 2011. - Vol. 2011. - P. 34-41. DOI: $10.1155 / 2011 / 951250$.

27. Reauer S. Vulvar lichen sclerosus. The importance of early clinical and histological diagnosis / S. Reauer // Hautartz. - 2004. - Vol. 55 (2). - P. 158-164.

28. Аполихина И. А. Папилломавирусная иноекция гениталий у женщин / И. А. Аполихина. - М. : ГЭОТАР-МЕД., 2002. - 112 c.

29. Nieuwenhof van de H. P. The etiologic role of HPV in vulvar squamous cell carcinoma fi ne tuned / H. P. van de Nieuwenhof, L. C. L. T. van Kempen, J. A. de Hullu // Cancer Epidemiol. Biomarkers Prev. - 2009. - Vol. 18 (7). - P. 20612067.

30. Nelson E. L. Vulvar intraepithelial neoplasia (VIN) and condylomata / E. L. Nelson, F. Bogliatto, C. K. Stockdale // Clin. Obstet. Gynecol. - 2015. - Vol. 58 (3). - P. 512-525.

31. Van de Nieuwenhof H. P. Lichen sclerosus and vulvar intraepithelial neoplasia in vulvar cancer / H. P. Van de Nieuwenhof. - Veghel, Germany, 2010. - P. 412-418. 
32. Vulvar and vaginal cancer, vulvar intraepithelial neoplasia 3 and vaginal intraepithelial neoplasia 3: Experience of a Referral
Institute / E. Siegler, Y. Segev, L. Mackuli [et al.] // Isr. Med. Assoc. J. - 2016. - Vol. 18 (5). - P. 286-289.

\section{REFERENCES}

1. Bokhman, Ya.V. (2002). Rukovodstvo po onkoginekologii [Guide to oncogynecology]. St. Petersburg: Foliant [in Russian].

2. Zharov, A.V., \& Vazhenin, A.V. (2005). Optimizatsiya lecheniya bolnykh rakom vulvy [Optimization of treatment of patients with vulvar cancer]. Chelyabinsk [in Russian].

3. Kaprin, A.D., Starinskiy, V.V., \& Petrova, G.V. (Eds.). (2016). Sostoyaniye onkologicheskoy pomoshchi naseleniyu Rossii v 2015 godu [The state of cancer care for the population of Russia in 2015]. Moscow: Moskovskiy Nauchno-Issledovatelskiy Onkologicheskiy Institut im. P.A. Gertsena - filial FGBU "NMIRTs" Minzdrava Rossii [in Russian].

4. Petrova, G.V., Kaprin, A.D., Gretsova, O.P., \& Starinskiy, V.V. (2015). Zlokachestvennyye novoobrazovaniya $v$ Rossii obzor statisticheskoy informatsii za 1993-2013 gody [Malignant neoplasms in Russia, a review of statistical information for 1993-2013]. Moscow [in Russian]

5. Manukhin, I.B., Kondrikov, N.I., \& Kraposhina, T.P. (2002). Zabolevaniya naruzhnykh polovykh organov u zhenshchin [Diseases of the external genital organs in women]. Izd-vo: MIA, Rossiya [in Russian].

6. Ashrafyan, L.A., Kharchenko, N.V., Kiselev, V.I., Sveshnikov, P.G., Stepanova, Ye.V., \& Babayeva, N.A. (2006). Rak vulvy: etiopatogeneticheskaya kontseptsiya [Vulvar cancer: etiopathogenetic concept]. Moscow: Molodaya gvardiya [in Russian].

7. Kaufman, R.D., Braun, D., \& Faro, S. (2009). Dobrokachestvennyye zabolevaniya vulvy $i$ vlagalishcha [Benign diseases of the vulva and vagina]. Mogilevskaya, N.I. (Ed.) (Transl.). Moscow: Binom [in Russian].

8. de Witte, C.J., van de Sande, A.J.M., van Beekhuizen, H.J., Koeneman, M.M., Kruse, A.J., \& Gerestein, C.G. (2015). Imiquimod in cervical, vaginal and vulvar intraepithelial neoplasia: a review. Gynecol. Oncol., 139 (2), 377-384.

9. Ashrafyan, L.A., \& Kiselev, V.I. (2007). Opukholi reproduktivnykh organov (etiologiya i patogenez) [Tumors of the reproductive organs (etiology and pathogenesis)]. Moscow: Dimitreyd Grafik Grupp [in Russian].

10. Khashukoyeva, A.Z., Otdelnova, O.B., \& Kupeyeva, Ye.S. (2012). Fotodinamicheskaya terapiya distoroficheskikh zabolevaniy vulvy $v$ sochetanii $s$ papillomavirusnoy infektsiyey [Photodynamic therapy of dystorophical diseases of the vulva in combination with human papillomavirus infection]. Lecheniye i profilaktika - Treatment and Prevention, 1 (2), 78-80.

11. Uilkinson, Ye.Dzh., \& Stoun, K. I. (2009). Bolezn vulvy. Klinicheskoye rukovodstvo [Vulvar disease. Clinical guidelines]. Moscow: Binom [in Russian].

12. Del Pino, M., Rodriguez-Carunchio, L., \& Ordi, J. (2013). Pathways of vulvar intraepithelial neoplasia and squamous cell carcinoma. J. Histopathology, 62 (1), 161-175.

13. Foster, D.C. (2002). Vulvar disease. Obstet. Gynecol., 100 (1), 145-163.

14. Disai, F.Dzh., \& Krisman, U.T. (2011). Klinicheskaya onkoginekologiya [Clinical gynecological oncology]. In 3 vols. Vol. 1. Novikova, Ye.G. (Ed.). Izd-vo: Rid Elsiver [in Russian].

15. Urmancheyeva, A.F., Tyulyandin, S.A., \& Moiseyenko, V.M. (2008). Prakticheskaya onkoekologiya: izbrannyye lektsii [Practical oncoecology: selected lectures]. St. Petersburg: Tsentr Tommi [in Russian].

16. Stehman, F.B., \& Look, K.Y. (2006). Carcinoma of the vulva. Obstet. Gynecol., 107 (3), 719-733.
17. Chovanec, J., Moukova, L., \& Feranec, R. (2013). Preinvasive lesions in gynecology - vulva. Klin. Onkol., 26, S44-S46.

18. (2011). ACOG Committee Opinion No. 509: Management of vulvar intraepithelial neoplasia // Obstet. Gynecol., 118 (5), 1192-1194.

19. Gorban, N.Y., Zadorozhna, T.D., Vovk, I.B., \&Zhulkevych, I.V. (2019). Morphological features of uterine polyps in females of reproductive age. Visnyk naukovykh doslidzhen - Bulletin of Scientific Research, 2, 47-52.

20. Zhulkevych, I.V., \& Kryvokulskyi, B.D. (2018). Personalizatsiia v onkolohii: indyvidualnyi pidkhid do profilaktyky tromboembolichnykh uskladnen pry panhisterektomii [Personalization in oncology: individual approach to the prevention of thromboembolic complications during hysterectomy]. Visnyk sotsialnoi hihiieny ta orhanizatsii okhorony zdorovia Ukrainy - Bulletin of Social Hygiene and Health Protection Organization of Ukraine, 4, 11-18 [in Ukrainian].

21. Cherenkov, V.G., Aleksandrova, I.V., \& Shpenkova, A.A. (2010). Rak vulvy: patogeneticheskiye varianty, diagnostika, lecheniye, plasticheskiye operatsii [Vulvar cancer: pathogenetic options, diagnosis, treatment, plastic surgery]. Opukholi zhenskoy reproduktivnoy sistemy - Tumors of the Female Reproductive System, 4, 78-82. Retrieved from: https://doi. org/10.17650/1994-4098-2010-0-4-78-82 [in Russian].

22. Wallbillich, J.J., Rhodes, H.E., \& Milbourne, A.M. (2012). Vulvar intraepithelial neoplasia (VIN 2/3): comparing clinical outcomes and evaluating risk factors for recurrence. Gynecol. Oncol., 127 (2), 312-315.

23. Horban, N.Y., Vovk, I.B., Lysiana, T.O., Ponomariova, I.H., \& Zhulkevych, I.V. (2019). Peculiarities of uterine cavity biocenosis in patients with different types of endometrial hyperproliferative pathology. J. Med. Life., 12 (3), 266-270.

24. Galaychuk, I.Y., Zhulkevych, I.V., Smiyan, S.I., Nykolyuk, V.D., \& Komorovsky, R.R. (2019). Boreliozna limfadenopatiia u praktytsi onkoloha (klinichni sposterezhennia). [Borrelious lymphadenopathy in oncology practice (clinical observations)]. Onkolohiia - Oncology, 21, 3, 250-253. DOI: 10.32471/oncology.26637928.t-21-3-2019-g.7896. Retrieved from: URL: https://www. oncology.kiev.ua/article/7896/boreliozna-limfadenopatiya-upraktici-onkologa-klinichni-sposterezhennya [in Ukrainian].

25. Chulkova, O.V., Novikova, Ye.G., \& Sokolov, V.V. (2006). Diagnostika i lecheniye fonovykh i predrakovykh zabolevaniy vulvy [Diagnostics and treatment of background and precancerous diseases of the vulva]. Prakticheskaya onkologiya - Practical Oncology, 7 (4), 197-204 [in Russian].

26. Ueda, Y., Enomoto, T., Kimura, T., Yoshino, K., Fujita, M., \& Kimura, T. (2011). Two distinct pathways to development of squamous cell carcinoma of the vulva. J. Skin Cancer., 34-41. DOI: 10.1155/2011/951250.

27. Reauer, S. (2004). Vulvar lichen sclerosus. The importance of early clinical and histological diagnosis. Hautartz, 55 (2), 158-164.

28. Apolikhina, I.A. (2002). Papillomavirusnaya infektsiya genitaliy $u$ zhenshchin [Papillomavirus infection of the genitals in women]. Moscow: GEOTAR-MED. [in Russian].

29. Nieuwenhof van de, H.P., van Kempen, L.C.L.T., \& de Hullu, J.A. (2009). The etiologic role of HPV in vulvar squamous cell carcinoma fi ne tuned. Cancer Epidemiol. Biomarkers Prev., 18 (7), 2061-2067. 
30. Nelson, E.L., Bogliatto, F., \& Stockdale, C.K. (2015). Vulvar intraepithelial neoplasia (VIN) and condylomata. Clin. Obstet. Gynecol., 58 (3), 512-525.

31. Van de Nieuwenhof, H.P. (2010). Lichen sclerosus and vulvar intraepithelial neoplasia in vulvar cancer. Veghel, Germany.
32. Siegler, E., Segev, Y., Mackuli, L., Auslender, R., Shiner, M., \& Lavie, O. (2016). Vulvar and vaginal cancer, vulvar intraepithelial neoplasia 3 and vaginal intraepithelial neoplasia 3: Experience of a Referral Institute. Isr. Med. Assoc. J., 18 (5), 286-289.

Отримано 09.10.20

Прийнято до друку 12.10.20

Електронна адреса для листування: katryxa11@meta.ua 